\title{
ANALISIS DAMPAK DOWNSIZING TERHADAP AGLOMERASI INDUSTRI DAN PEREKONOMIAN DI JAWA TIMUR
}

\author{
(Studi Kasus 5 Daerah Aglomerasi di Jawa Timur Tahun 2016-2017) \\ Wening Purbatin Palupi Soenjoto \\ STITNU Al Hikmah Mojokerto \\ weningblackberry@gmail.com
}

\begin{abstract}
This study is a qualitative study to examine the Analysis of the Impact of Downsizing on Economic Industry Agglomeration in East Java, which explains the application of downsizing to deal with uncertainties that pose a risk to the company, which can hinder the achievement of company goals. This study focuses on the impact of downsizing on economic agglomeration in East Java. The purpose of this study is to provide a conclusion about the impact of downsizing by the company to save the company in a state because companies generally refocus on their core business. The effectiveness of the company increases as the company varies slightly, allowing the high-level management team to better understand and manage the remaining businesses. This study uses a qualitative approach with a case study method and is described in descriptive analysis. The data analyzed is the result of the interview. The benefits obtained are that the company will be more structured, so that if a problem occurs, it can be seen what problems are occurring, how to overcome them and whether the problem has been resolved or something has not been resolved, but still various further research is needed. by using other research methods to strengthen research results and add insight academically and economically.
\end{abstract}

Keywords: downsizing, agglomeration, human resources, economy

\begin{abstract}
Abstrak
Penelitian ini merupakan penelitian kualitatif untuk meneliti Analisa Dampak Downsizing Terhadap Aglomerasi Industri dan Perekonomian di Jawa Timur adalah menjelaskan penerapan downsizing untuk menghadapi ketidakpastian yang menimbulkan suatu risiko bagi perusahaan, yang dapat menghambat pencapaian tujuan perusahaan. Dalam penelitian ini berfokus pada dampak downsizing terhadap aglomerasi ekonomi di Jawa Timur. Tujuan dari penelitian ini adalah memberikan suatu kesimpulan tentang dampak downsizing yang dilakukan perusahaan untuk menyelamatkan perusahaan dalam keadaan karena perusahaan umumnya memfokuskan ulang pada bisnis inti (core) mereka. Efektivitas perusahaan meningkat karena perusahaan menjadi sedikit bervariasi, mngijinkan tim manajemen tingkat tinggi lebih baik mengerti dan mengatur bisnis yang terisisa. Penelitian ini menggunakan pendekatan kualitatif dengan metode studi kasus dan diuraikan secara analisis deskriptif. Data yang dianalisis adalah hasil wawancara Manfaat yang didapat yaitu perusahaan akan lebih terstruktur, sehingga jika terjadi suatu masalah dapat diketahui masalah apa saja yang terjadi, bagaimana cara menanggulanginya dan apakah masalah tersebut sudah terselesaikan atau ada yang belum terselesaikan namun tetap
\end{abstract}


dibutuhkan penelitian lebih lanjut yang beragam dengan menggunakan metode penelelitian lain untuk memperkuat hasil penelitian maupun menambah wawasan secara akademis dan bidang ekonomi.

Kata kunci: Downsizing, aglomerasi, sumber daya manusia, ekonomi

\section{PENDAHULUAN}

Jawa Timur memiliki 5 daerah aglomerasi industri skala besar yaitu: Pasuruan, Sidoarjo, Gresik, Mojokerto dan Lamongan menjadi penggerak mobilitas ekonomi dan mendukung pemusakan daerah sehingga terjadi adanya penyerapan tenaga kerja dan penerapan uang minimum regional (UMR) yang lebih besar dibandingkan daerah-daerah lainnya,bahkan penerapan tata kelola kota dan peraturan daerah menjadi berbeda pula dengan daerah non aglomerasi. Mengikuti perkembangan jaman, permintaan konsumen yang saat ini sangat beraneka ragam sehingga para produsen penggiat ekonomi banyak membangun perusahaan besar dan menyerap tenaga kerja.Namun di sisi lain menjadi masalah-masalah baru yang muncul saat terjadi berkumpulnya banyak perusahaan dalam satu daerah. Polusi udara dan tanah menjadi perhatian dalam kajian amdal. Efek ekonomi yang terjadi sangat berperan dan berdampak bagi produsen,para pekerja dan lingkungan sekitar aglomerasi. Daerah aglomerasi menjadi penyokong pendapatan daerah yang juga berdampak pada pendapatan nasional sehingga akan terjadi pembangunan ekonomi sebagai proses yang progressif terhadap meningkatnya pendapatan keseluruhan yang berkelanjutan dengan memperhatikan pemerataan pendapatan dan pertambahan penduduk termasuk adanya perubahan keadaan ekonomi suatu negara.

Dalam berbisnis, perusahaan akan berusaha untuk meraih kesuksesan dapat diraih dengant produktifitas yang selalu meningkat lakukan survei pasar secara teratur dan menganalisa perubahan yang terjadi.Downsizing dan aglomerasi merupakan dua fenomena ekonomi yang berlawanan namun berkaitan dan saling mempengaruhi sehingga membutuhkan tata kelola yang maksimal di berbagai aspek.Namun kebijakan pemerintah dan keadan realita di masing-masing perusahan memiliki perbedaan yang tidak bisa diabaikan. Setiap perusahaan memiliki media dan proses khas yang terdiri atas perencanaan, pengorganisasian, pelaksanaan serta pengawasan yang dilakukan untuk menentukan usaha mencapai sasaran-sasaran dengan memanfaatkan sumber daya manusia dan sumber daya lainnya. Dalam membagi-bagikan tugas serta jenisnya kepada semua karyawan dengan pemberian kewenangan serta tanggung jawab yang tegas dan jelas.

Sumber daya manusia menjadi motor penggerak dalam perusahan.Setiap karyawan memiliki tugas sesuai yang ditentukan perusahaan dan disesuaikan dengan keterampilan masingmasing karyawan. Setiap karyawan hendaknya diberikan wewenang sepenuhnya untuk melaksanakan tugasnya dengan baik serta dapat mempertanggungjawabkannya kepada atasan secara langsung dengan bentuk aksi dan proses yang dilakukan harus mempunyai tujuan yang 
sama serta dipimpin oleh seorang atasan langsung yang didasarkan pada rencana dan tujuan kerja yang sama.

Perusahan-perusahaan yang sudah berjalan dengan mobilitas ekonomi yang stabil dan progresif maka tata kelola perusahaan menjadi kunci penting selain harus adanya adaptasi dengan berbagai macam kebjikan baik kebijakan dari pemerintah maupun daerah. Dalam proses aktifitas perusahaan yang bertujuan meningkatkan produktivitas, ROI serta kualitas hidup manusia berdasarkan tindakannya pada aspek kuantitatif serta perilaku sumber daya manusia di masing-masing perusahaan akan menghadapi isu inflasi, sumber daya (resource) yang makin langka, nilai sosial budaya masyarakat, teknologi, hubungan karyawan dan manajemen, etika dan tanggung jawab sosial, konflik-konflik serta globalisasi. menghadapi masalah yang datang dari sektor industri sehingga menuntut informasi yang dibutuhkan melalui sistem informasi manajemen yang baik.

Di Indonesia masih banyak sektor industri yang sifatnya UMKM dan industri sektor besar lebih dominan disokong oleh investor Industri dinilai sebagai suatu kegiatan ekonomi yang melakukan kegiatan mengubah suatu barang dasar secara mekanis, kimia, atau dengan tangan sehingga menjadi barang jadi atau setengah jadi dan atau barang yang kurang nilainya menjadi barang yang lebih tinggi nilainya, dan sifatnya lebih dekat kepada pemakai akhir . Kawasan Industri menjadi kawasan tempat pemusatan kegiatan industri yang dilengkapi dengan prasarana dan sarana penunjang yang dikembangkan dan dikelola oleh perusahaan kawasan industri yang telah memiliki izin usaha kawasan industri sehingga terjadi simbiosis mutualisme bagi daerah yang terdampak pula.

Ditinjau dari teori aglomerasi adalah konsentrasi spasial dari aktivitas ekonomi di kawasan perkotaan karena penghematan akibat lokasi yang berdekatan (economies of proximity) yang diasosiasikan dengan kluster spasial dari perusahaan, para pekerja dan konsumen. Mobilitas bisnis yang dilalui oleh sebuah perusahaan tidaklah selalu berjalan sesuai rencana. Tidak jarang rencana yang sudah dibuat untuk meningkatkan produktifitas bisnis yang diharapkan penjualan tidak terjadi. Victims dan Survivors dalam proses downsizing, bila terjadinya berkelanjutan, maka dapat mendorong perusahaan pada situasi krisis keuangan. Cepat atau lambat akan berimbas kepada kemampuan perusahaan untuk mendanai biaya biaya tetapnya, terutama biaya tenaga kerja. Banyak langkah yang dilakukan oleh perusahaan dalam situasi krisis keuangan. Untuk memastikan bahwa biaya biaya tenaga kerjanya tidak meningkat. Dalam kasus yang lebih serius harus diturunkan. Langkah tersebut dilakukan sebelum upaya downsizing sepenuhnya.Secara umum downsizing didefinisikan sebagai upaya yang dilakukan oleh perusahaan untuk pengurangan jumlah tenaga kerja dan atau biaya tenaga kerja yang bertujuan untuk menghemat biaya tetap dengan tetap memusatkan perhatian kepada misi, sasaran dan nilai nilai perusahaan, dengan tujuan untuk tetap dapat mempertahankan kelangsungan hidup perusahaan dilakukan. Dalam prakteknya tidak semua strategi diadopsi dan dilaksanakan oleh perusahaan saat mengalami krisis keuangan. Dalam kasus yang paling ekstrim, bahkan ada kecenderungan pada 
sejumlah perusahaan untuk langsung melakukan upaya downsizing, dengan melakukan pemutusan hubungan kerja (Montgomery dalam Kuncoro , 2002).

Perkembangan era makin memperlihatkan tentang kegiatan gerakan ekonomi khususnya tidak dapat lagi dilihat sebagai sebuah kegiatan dalam memproduksi barang maupun jasa melalui kegiatan manufaktur dan pelayanan. Praktek ekonomi saat ini melibatkan kegiatan penyediaan barang dan jasa bagi para konsumen. Perkembangan ekonomi yang pesat, barang dan jasa menjadi sesuatu yang sangat dibutuhkan. Dengan perkembangan ini, pendekatan manajemen pun tidak lagi hanya terfokus bagaimana melakukan, misalnya, efisiensi dalam proses pembuatan barang di pabrik, akan tetapi juga harus mulai merumuskan bagaimana penyediaan jasa dapat dilakukan secara efektif dan sekaligus juga efisien. Termasuk isu yang terkait dengan ekonomi jasa ini adalah juga mengenai isu hak-hak kekayaan intelektual atau property rights. Sebagai bentuk dffrensiasi produk dan usaha dalam bertahan di dunia bsnis serta kemampuan membaca peluang di pasar global seperti saat ini.

Berdasarakan penjelasan diatas maka peneliti tertarik meneliti di 5 daerah Aglomerasi Industri besar di Jawa Timur tentang Analisa Dampak Downsizing Terhadap Aglomerasi Industri Dan Perekonomian di Jawa Timur. Namun untuk menambah khasanah dan manfaat secara akademik maka penelitian ini perlu dikembangakan kembali dengan metode penelitian yang lain sehingga keragaman analisa yang lebih valid dapat lebih bermanfaat.

\section{KAJIAN LITERATUR}

Aglomerasi adalah konsentrasi spasial dari aktivitas ekonomi di kawasan perkotaan karena penghematan akibat lokasi yang berdekatan (economies of proximity) yang diasosiasikan dengan kluster spasial dari perusahaan, para pekerja dan konsumen. Sehingga aglomerasi yang terjadi mampu meningkatkan produktivitas hasil industri dan mutu produk,memberikan kemudahan bagi kegiatan industri dan mempermudah kontrol dalam hubungan tenaga kerja, bahan baku dan pemasaran (Kuncoro 2002 ).

Aglomerasi dapat dibagi menjadi 2 yaitu;

1. Aglomerasi Primer adalah Perusahaan yang baru muncul tidak ada hubungan dengan perusahaan lama yang sudah terdapat di wilayah aglomerasi.

2. Aglomerasi Sekunder adalah jika perusahaan yang baru beroperasi adalah perusahaan yang memiliki tujuan untuk memberi pelayanan pada perusahaan yang lama.

Melakukan pemerataan lokasi industri sesuai dengan jumlah secara tepat dan berdaya guna serta menyediakan fasilitas kegiatan industri yang berwawasan lingkungan. Proses aglomerasi (pemusatan) industri keberhasilannya banyak ditentukan oleh faktor teknologi lingkungan, produktivitas, modal, SDM, manajemen dan lain-lain. Negara-negara yang sedang mengalami aglomerasi industri, terjadi dualisme bidang teknologi yaitu suatu keadaan dalam suatu bidang ekonomi tertentu yang menggunakan tehnik dan organisasi produksi yang sangat berbeda karakteristiknya sehingga mengakibatkan perbedaan besar pada tingkat produktivitas di sektor modern dan sektor tradisional, seperti keadaan berikut ini : 
1. Jumlah penggunaan modal dan peralatan yang digunakan.

2. Penggunaan pengetahuan teknik, organisasi, dan manajemen.

3. Tingkat pendidikan dan keterampilan para pekerja.

Gejala Aglomerasi Disebabkan oleh:

1. Persaingan industri yang semakin hebat dan semakin banyak

2. Pelaksanaan segala bentuk efisien dalam penyelenggaraan industry

3. Peningkatan produktivitas hasil industry dan mutu produksi

4. Pemberian kemudahan bagi kegiatan industri

5. Kemudahan control dalam hubungan tenaga kerja

6. Persiapan menyongsong perdagangan bebas di kawasan ASIA pasifik yang dimulai tahun 2020

7. Pemerataan lokasi industry sesuai gengan jumlah secara tepat dan berdaya guna serta menyediakan industry yang berwawasan lingkungan

Menurut Perroux terjadinya aglomerasi industri mempunyai keuntungan-keuntungan tertentu yaitu skala ekonomis (usaha dalam jumlah besar) dan keuntungan penghematan biaya (Arsyad, 1999: 356), yaitu :

1. Keuntungan Internal Perusahaan

Keuntungan ini muncul karena adanya faktor-faktor produksi yang tidak dapat dibagi yang hanya diperoleh dalam jumlah tertentu. Kalau dipakai dalam jumlah yang lebih banyak, biaya produksi per unit akan jauh lebih rendah dibandingkan jika dipakai dalam jumlah yang lebih sedikit.

2. Keuntungan Lokalisasi (Localization Economies)

Keuntungan ini berhubungan dengan sumber bahan baku atau fasilitas sumber. Artinya dengan menumpuknya industri, maka setiap industri merupakan sumber atau pasar bagi industri yang lain.

3. Keuntungan Ekstern (keuntungan urbanisasi)

Aglomerasi beberapa industri dalam suatu daerah akan mengakibatkan banyak tenaga kerja yang tersedia tanpa membutuhkan latihan khusus untuk suatu pekerjaan tertentu dan semakin mudah memperoleh tenaga-tenaga yang berbakat. Selain itu aglomerasi akan mendorong didirikannya perusahaan jasa pelayanan masyarakat yang sangat diperlukan oleh industri, misal : listrik, air minum, maka biaya dapat ditekan lebih rendah.

Model aglomerasi industri yang berkembang akhir-akhir ini, dapat dikategorikan menguntungkan, di antaranya adalah: mengurangi pencemaran atau kerusakan lingkungan, karena terjadi pemusatan kegiatan sehingga memudahkan dalam penanganannya; mengurangi kemacetan di perkotaan, karena lokasinya dapat disiapkan di sekitar pinggiran kota; memudahkan pemantauan dan pengawasan, terutama industri yang tidak mengikuti ketentuan yang telah disepakati; tidak mengganggu rencana tata ruang; dapat menekan biaya transportasi dan biaya produksi serendah mungkin. 
Penyebab terjadinya aglomerasi industri antara lain;

1. Terkonsentrasinya beberapa faktor produksi yang dibutuhkan pada suatu lokasi

2. Kesamaan lokasi yang didasarkan pada satu faktor produksi tertentu

3. Adanya wilayah pusat pertumbuhan industri yang disesuaikan dengan tata ruang \& fungsi wilayah

\section{Pengertian Downsizing}

Salah satu cara untuk mengubah struktur organisasi yaitu dengan cara melakukan downsizing. Downsizing adalah prubahan struktur yang dilakukan sebuah perusahaan dengan tidak mengurangi keefektifan produktifitas dari perusahaan itu sendiri untuk mengurangi jumlah tenaga kerja yang dianggap sudah tidak efektif atau bahkan jumlah unit operasi. Bahasa kasarannya ialah PHK. Ada beberapa penyebab yang menjadikan sebuah perusahaan melakukan downsizing :

1. Krisi ekonomi yang dalami oleh perusahaan

2. Pendapatan perusahaan lebih kecil ketimbang pengeluaran

3. Jumlah tenga kerja yang terlampau banyak

4. Butuh tenaga kerja yang lebih professional dan personalia yang baru

5. Perusahaan ingin membuka cabang baru

\section{Dampak Downsizing}

Pelaksanaan downsizing menyebabkan bertambahnya angka pengangguran yang terjadi dalam negara yang bersangkutan, bagi pihak yang di PHK, hal ini mengurangi komitmen mereka dalam mengkonsumsi maupun memperkenalkan produk yang dihasilkan oleh perusahaan dahulu mereka bekerja. Para pekerja akan memprepsikan bahwa perusahaan tidak adil dan kurang fair sehingga menurunkan keterampilan dan produktivitas mereka dalam dunia kerja.Kurangnya komitmen ini tidak hanya berdampak pada naiknya absensi dan menurunnya ketekunan, tapi juga menurunnya produktivitas. Inilah yang menyebabkan perusahaan gagal mencapai tujuan downsizing. (Meyer et. Al 1998).

\section{METODE PENELITIAN}

\section{Pendekatan Penelitian}

Penelitian ini menggunakan pendekatan penelitian kualitatif dimana penelitian kualitatif sebagai metode ilmiah sering digunakan dan dilaksanakan oleh peneliti untuk menganalisa secra detail penelitian ini. Sejumlah alasan dikemukakan,intinya bahwa penelitian kualitatif mampu memperkaya hasil penelitian. Penelitian kualitatif dilaksanakan untuk membangun pengetahuan melalui pemahaman dan penemuan yang diuraikan secara analisa deskriptif. Pada pendekatan penelitian kualitatif menjadi sebuah proses penelitian dan pemahaman yang berdasarkan pada metode yang menyelidiki dampak downsizing pada para pekerja dan masalah 
perusahaan yang menerapkan sistem downsizing. Pada penelitian ini peneliti membuat suatu gambaran kompleks, meneliti kata-kata, laporan terinci dari pandagan responden melalui wawancara secra tebuka agar memudahkan mendapatkan informasi yang lebih detail dan melakukan studi pada situasi yang alami yaitu dengan cara berinteraksi langsung dengan responden yang diteliti.

Penelitian kualitatif dilakukan pada kondisi alamiah dan bersifat penemuan. Dalam penelitian kualitatif, peneliti adalah instrument kunci. Oleh karena itu peneliti harus memiliki bekal teori dan wawasan yang luas jadi bisa bertanya, menganalisis dan mengkonstruksi objek yang dilteliti menjadi lebih jelas. Penelitian ini lebih menekankan pada makna dan terikat nilai.Hakikat penelitian kualitatif adalah mengamati orang dalam lingkungan hidupnya berinteraksi dengan mereka, berusaha memahami bahasa dan tafsiran mereka tentang dunia sekitarnya, mendekati atau berinteraksi dengan orang-orang yang berhubungan dengan focus penelitian dengan tujuan mencoba memahami, menggali pandangan dan pengalaman mereka untuk mendapat informasi atau data yang diperlukan (Iskandar, 2009).

\section{Subjek Penelitian}

Subjek penelitian berjumlah 250 orang yang diambil 50 pekerja mewakili daerah aglomerasi terbesar di Jawa Timur. Untuk menjaga etika dan kepercayaan responden,penelti tidak menjelaskan nama perusahaan tempat para pekerja Para pekerja berusia antara 20-45 tahun dengan total:

1. 150 pekerja sudah bekerja lebih 10 tahun

2. 100 pekerja sudah bekerja dibawah 10 tahun

\section{Teknik Pengambilan Data}

Dilakukan wawancara terbuka untuk dapat menggali data terhadap 250 pekerja yang tersebar di 5 perusahaan pada daerah aglomerasi terbesar di Jawa Timur.

\section{Data Primer}

10 pertanyaan pada 250 pekerja untuk memenuhi data primer:

a. Apakah anda paham UU Tenaga Kerja

b. Apakah anda paham tentang system penggajian?

c. Apakah anda sebelum menjadi pekerja,melewati proses rekruitmen?

d. Apakah anda paham sistem outsourcing?

e. Apakah anda setuju adanya outsoucing?

f. Apakah anda paham bahwa downsizing itu juga merupakan kata lain dari PHK?

g. Apakah saat proses rekruitmen, dijelaskan sistem PHK?

h. Apakah anda termasuk anggota serikat buruh?

i. Apakah jika anda keluar dari pekerjaan mendapat pesangon?

j. Bagaimana pendapat anda tentang PHK? 


\section{Data Sekunder}

Diambil dari hasil wawancara secara terbuka kepada 5 manajer perusahan yang mewakili 5 perusahaan di daerah aglomerasi terbesar di Jawa Timur. Namun data hasil wawancara tidak terlalu detail karena pihak perusahaan memiliki hak menjawab dengan mengkondisikan keadaan data perusahaan yang harus dijaga kerahasiaannya termasuk sistem PHK,outsourcing dan penggajian sehingga hasil wawancara mejadi data pendukung semata.

Data dari BPS dan UU ketenagakerjaan,penggajian serta sistem outsourcing masing belum bisa mejadi benang merah yang memiliki korelasi maupun pengaruh yang signifikan dengan penelitian ini karena hasil wawancara terbuka dengan 250 pekerja lebih pada keadaan realita yang dirasakan para pekerja yang memilih mengikuti aturan perusahaan daripada di PHK.

3. Lokasi dan Waktu Penelitian
a. Bulan Januari 2017 di Sidoarjo
b. Bulan Februari 2017 di Gresik
c. Bulan Maret 2017 di Lamongan
d. Bulan April 2017 di Mojokerto
e. Bulan Mei 2017 di Pasuruan

\section{HASIL DAN PEMBAHASAN}

\section{Hasil}

Dari hasil wawancara secara terbuka terhadap 250 pekerja,terbukti bahwa rata-rata mereka hanya bekerja Tanya mengetahui secara detail tentang UU ketenagakerjaan,sistem penggajian hingga perihal outsourcing. Walaupun para pekerja melewati proses rekruitmen sesuai aturan yang diberlakukan masing-masing perusahaan.Pihak perusahaan baik secara sengaja maupun tidak sengaja meiliki aturan atau kebijakan untuk tidak menjelaskan secara detail manajemen ketenagakerjaan termasuk sistem penggajian dan pengembangan karir. Pihak perusahaan mempunyai alasan bahwa para pekerja lebih banyak dibidang produksi dan bukan manajerial sehingga kebutuhan lebih pada skill untuk mengembangakn produktifitas gerak mobilitas perusahaan dan memang para pekerja tidak menuntut adanya pengembangan karir.

Kurang pengetahuan,edukasi dan sosialisasi tentang ketenagakerjaan,sistem PHK dan pengajian dirasakan para pekerja,selain mereka juga kurang membaca namun memang minimnya edulasi dan sosialisasi perihal tersebut.bagi para pekerja,tidak di PHK,mengikuti aturan perusahaan dan menerima gaji tanpa banyak protes dinilai lebih baik karena semakin sulitnya mencari pekerjaan. Sikap kondusif dan kooperatif yang dilakukan para pekerja karena adanya rasa takut di PHK dan juga menyadari sulitnya mencari pekerjaan baru.

Jika dikaitkan berdasarkan data dari Badan Pusat Statistik (BPS) telah melakukan Sensus Ekonomi 2016. Dari hasil sensus, jumlah perusahaan di Indonesia tercatat ada sebanyak 26,7 
juta. Angka ini meningkat dibanding hasil sensus ekonomi 2006 yang sebanyak 22,7 juta perusahaan. Artinya, ada 3,98 juta perusahaan baru dalam 10 tahun terakhir. Perkembangan jumlah penduduk dan tumbuhnya usaha modern seperti bisnis online memberikan andil meningkatnya aktivitas ekonomi di Indonesia. Jumlah perusahaan pada Sensus Ekonomi 2016 ini meningkat 17,51\% dibanding dengan jumlah pada 2006. Maka pada tahun 2019 ini dapat diperkirakan makin meningkatkan jumlah perusahaan di Indonesia larena faktor-faktor pendukung makin memperkuat dan kesempatan bersaing di pasar global makin meluas. Bila dibedakan menurut skala usaha, 26,26 juta usaha (98,33\%) berskala Usaha Mikro Kecil (UMK) dan 450.000 perusahaan berskala Usaha Menengah Besar (UMB).Jadi jumlah perusahaannya banyak, tapi kecil-kecil,Perusahaan ini umumnya bergerak di sektor Perdagangan Besar dan Eceran; Reparasi dan Perawatan Mobil dan Sepeda Motor sebanyak 12,3 juta atau 46,17\% dari seluruh perusahaan yang ada di Indonesia.

Aglomerasi industri yang berkembang masih banyak menimbulkan polemik dan konflik,antara kebutuhan mobilitas produksi perusahaan yang berdampak pada bergrak pula kegiatan perekonomian. Perusahaan-perusahaan yang berada di daerah aglomerasi adalah perusahan manufaktur yang paling dominan di Jawa Timur. Jika dlhat dari data BPS 2016 menyatakan Jawa Timur masih menduduki peringkat pertama di Indonesia.Selain itu, banyak juga yang bergerak di bidang usaha penyediaan akomodasi dan penyediaan makan minum $(16,72 \%)$ serta industri pengolahan(16,53\%). Berdasarkan sebaran yang terjadi sekitar 79,53\% perusahaan berada di Pulau Jawa dan Sumatera. Hanya kurang dari 20\% saja yang berada di luar Jawa dan Sumatera. Sebagian besar masih terkonsentrasi di Jawa. (https://finance.detik.com/berita-ekonomi-bisnis/d-3485474/).

Pertumbuhan jumlah perusahaan yang makin meningkat maka akan memicu adanya aglomerasi industri dalam bentuk pemusatan industri di suatu kawasan tertentu dengan tujuan agar pengelolanya dapat optimal. Gejala aglomerasi industri itu disebabkan adanya persaingan industri yang semakin banyak.Melaksanakan segala bentuk efisiensi di dalam penyelenggaraan industri. Namun pada realita yang terjadi dari adanya aglomerasi di Jawa Timur masih belum mampu menerap tenaga kerja secara optmal dikarenakan banyak perusahaan yang sudah menggunakan teknologi dan tenaga kerja sebagai oerator mesinnnya.sehingga dampak ekonominya masih belum dirasakan secara luas. Daerah sekitar aglomerasi yang terdampakpun belum menunjukkan adanya peningkatan perekonomian yang lebih menonjol.

Tenaga kerjanyapun yang bekerja di daerah aglomerasi lebh banyak dari pendatang sehingga penyerapan tenaga kerja di sekitar daerah aglomerasi malah minim. Berdasarkan hasil wawancara dengan penduduk daerah sekitar aglomerasi menyatakan bahwa proses rekruitmen cenderung pada tenaga kerja yang punya keahlian yang disesuaikan kebutuhan perusahaan mejadi penyebabnya minim tenaga kerja yang berasal dari daerah sekitar aglomerasi.

Dari hasil penelitian ini maka penelti menguraikan juga dampak dari aglomerasi industri pada 5 daerah aglomersi di Jawa Timur. 
1. Dampak ekonomi, meliputi:

a. Peningkatan produksi dan pendapatan yang memberi PDB pada masing-masing daerah aglomerasi

b. Pengurangan pengangguran dengan adanya penyerapam tenaga kerja yang melalui proses rekrutmen

c. Pengaruh langsung dari dampak ini pada umumnya dirasakan oleh masyarakat sekitar lokasi dengan tumbuhnya gerakan ekonomi penunjang seperti adanya kos-kos an,lahan parker,warung-warung sebagai bentuk simbiosis mutualisme industri tersebut untuk kemudian meluas ke daerah dan bahkan mungkin ke tingkat nasional.

2. Dampak Lingkungan

Adapun klasifikasi dampak lingkungan adalah sebagai berikut:

a. Kelompok dampak lingkungan alam Flora dan fauna penghidupan serangga organisme serta makhluk ekologi dalam tanah dan air dapat rusak karena adanya polusi tanah dan air.

b. Kelompok dampak lingkungan manusia:makin banyaknya pendatag sebagai pekerja sehingga bertambahnya kepadatan penduduk.

c. Keindahan lingkungan fisik dan alam dapat berubah karena makin minimnya lahan hijau.

d. Keindahan daerah perkotaan dan pedesaan termasuk pemandangan dan kemungkinan untuk dinikmatinya menjadi berkurang karena lahan diperluas untuk pergerakan usaha.

3. Dampak Pemanfaatan:

a. Kelompok dampak terhadap kesehatan, keamanan dan kenyamanan; Terhadap kenyamanan dan keamanan pejalan kaki melalui lalu lintas dan lalu lalang

b. Kelompok dampak terhadap sosial budaya; Terjadi karena terpecahnya atau terganggunya masyarakat atau kelompok yang ada

c. Dampak Sosial Budaya

d. Dampak Kesejahteraan Umum

Memiliki 3 aspek, yaitu:

1) Jenis varian munculnya gerakan ekonomi

2) Intensitas yang dipengaruhi mobilitas industry masing-masing perusahaan

3) Daerah menjadi bentuk daerah aglomerasi industry,daerah sekitar aglomerasi industri dan daerah yang terdampak aglomerasi industru

\section{Pembahasan}

Keadaan ekonomi yang sifatnya fluktuatif dan dipengaruhi multi dimensi termasuk factor politik yang mapu menggerakan keadaan ekonomi dunia. Faktor dari luar negri hingga kebijakan yang diterapkan pemerintah menjadi perhatian semua perusahaan terutama perusahaanperusahab sektor besar dan adanya penanaman modal baik dari dalam maupun luar negeri. Saat ini perusahaan-perusahaan yang fokus dalam menghasilkan banyak produk dan juga fokus pada 
pasarnya, banyak yang telah menerapkan restrukturasi. Walaupun restrukturasi digunakan secara umum untuk mengatasi permasalahan akuisisi yang tidak sesuai dengan harapan perusahaan, perusahaan terkadang menggunakan strategi ini karena adanya perubahan yang mereka deteksi di lingkungan eksternal. Restrukturasi adalah strategi yang mana perusahaan merubah set-ofbusiness nya atau struktur keuangannya. Namun dampak restrukturisasi inilah yang salahs atunya berbentuk downsizing atau pemutusan hubungan kerja.

Masalah aglomerasi industri tidak terlepas adanya penyerapan tenaga kerja yang tidak bisa dihilangkan kasus rentan downsizing .UU dan kebijakan dari pemerintah dan daerah masih belum tersosialisasi secara optimal karena bisa ditilik dari tujuan perusahaan yang memang melakukan strategi profit oriented. Ada 3 faktor yang menjadi alasan perusahaan industri dalam menentukan lokasi, yaitu Perbedaan biaya tranportasi, perbedaan biaya upah dan keuntungan dari aglomerasi. terjadinya aglomerasi industri mempunyai keuntungan-keuntungan tertentu yaitu skala ekonomis (usaha dalam jumlah besar) dan keuntungan penghematan biaya yaitu Keuntungan Internal Perusahaan keuntungan Estern (keuntungan Urbanisasi) dan Keuntungan lokalisasi (localiitatiom Economies). Masih jadi polemic terkait masalah sistem penggajian an ketenagakerjaan yang rentang terjadinya downsizing. Minimnya edukasi dan sosialisai yang dilakukan pihak perusahaan dan kepekaan para pekerja untuk mempelajari tentang UNdang-undang ketenagakerjaan.

Menurut Undang - Undang No. 13 pasal 61 tahun 2003 mengenai tenaga kerja, perjanjian kerja dapat berakhir apabila :

1. Pekerja meninggal dunia

2. Jangka waktu kontak kerja telah berakhir

3. Adanya putusan pengadilan atau penetapan lembaga penyelesaian perselisihan hubungan industrial yang telah mempunyai kekuatan hukum tetap

4. Adanya keadaan atau kejadian tertentu yang dicantumkan dalam perjanjian kerja, peraturan perusahaan, atau perjanjian kerja bersama yang dapat menyebabkan berakhirnya hubungan kerja.

Pihak yang mengakhiri perjanjian kerja sebelum jangka waktu yang ditentukan, wajib membayar ganti rugi kepada pihak lainnya sebesar upah pekerja atau buruh sampai batas waktu berakhirnya jangka waktu perjanjian kerja.namun yang terjadi di lapangan,penerapan kebijakan ini tidak diberlakuakan.Namun realita lapangan beradasrkan hasil wawancara,pihak perusahan sangat tertutup untuk hal tata kelola pegawai terutama terkait penerapan pemutusan tenaga kerja dan sistem outsourching. Pihak tenaga kerja tidak mampu melakukan protes dan hanya menerima hasil keputusan dari perusahaan.

Tata kelola dan manajemen perusahaan saat ini juga tidak bisa mengabaikan tercapainya kualitas. Kualitas akan menentukan kompetensi dan kemampuan untuk berkompetisi dengan yang lain, disamping kualitas juga akan menentukan biaya dalam jangka panjang. Kualitas juga merupakan indikator tercapainya produktifitas sehingga reaksi pasar dapat dikendalikan secara 
berkelanjutan.Faktor penentu lokasi merupakan kualitas suatu wilayah yang terkait dengan daya tarik wilayah tersebut terhadap keputusan investasi dari calon investor yang memiliki keyakinan untuk menanamkan modalnya..Ragam faktor yang digunakan sebagai bahan pertimbangan untuk menentukan dimanakah seharusnya lokasi industri yang tepat. Kegiatan yang produktif akan memilih lokasi yang dapat memperoleh input secara efisien. Input tersebut tidak hanya berbentuk fisik, tetapi juga berbentuk jasa, seperti jasa prasarana dan sarana, institusi pendukung, maupun kualitas sumberdaya manusia .

Jawa Timur memiliki 5 daerah aglomerasi terbesar yang sudah memiliki sistem manajemen yang terkontrol dengan baik. Perusahaan- perusahaan yang berada di daerah aglomerasi sangat berdampak pada perekonomian daerah sekitarnya,memberikan pajak bagi daerah setempat dan juga sangat mempengaruhi sistem UMR nya pula. Aglomerasi tetap memperhatikan lokasi yang tepat agar tujuan perusahaan dapat tercapai.analisa lahan dalam menyelidiki tata ruang (spatial order) yang berdampak pada kegiatan ekonomi.Lahan industry ini menjadi sumber-sumber yang potensial serta hubunganya dan pengaruhnya terhadap keberadaan berbagai macam usaha atau kegiatan lain, baik ekonomi maupun sosial.

Dalam teori ini bahwa aglomerasi muncul karena para pelaku ekonomi berupaya mendapatkan penghematan aglomerasi (agglomeration economies), baik karena penghematan lokalisasi maupun penghematan urbanisasi, dengan mengambil lokasi yang saling berdekatan satu sama lain ( Kuncoro, 2002: 26). Aglomerasi ini mencerminkan adanya sistem interaksi antara pelaku ekonomi yang sama: apakah antar perusahaan antara industri yang sama, antar perusahaan antara industri yang berbeda, ataupun antar individu, perusahaan dan rumah tangga. Di lain pihak, kota adalah suatu daerah keanekaragaman yang menawarkan manfaat kedekatan lokasi konsumen maupun produsen.

Pada teori ekonomi geografi baru berupaya untuk menurunkan efek-efek aglomerasi dari interaksi antara besarnya pasar, biaya transportasi dan increasing return dari perusahaan.Dalam hal ini ekonomi aglomerasi tidak diasumsikan tetapi diturunkan dari interaksi ekonomi skala pada tingkat perusahaan, biaya transportasi dan mobilitas faktor produksi.Teori ekonomi geografi baru menekankan pada adanya mekanisme kausalitas sirkular untuk menjelaskan konsentrasi spasial dari kegiatan ekonomi (Krugman dan Venables dalam Martin \& Ottavianno, 2001).

Dalam model tersebut kekuatan sentripetal yang diterapkan tata kelola perusahaan berasal dari adanya variasi konsumsi atau beragamnya intermediate good pada sisi produksi. Kekuatan sentrifugal berasaldari tekanan yang dimiliki oleh konsentrasi geografis dari pasar input lokal yang menawarkan harga lebih tinggi dan menyebarnya permintaan. Jika biaya transportasi cukup rendah maka akan terjadi aglomerasi.Namun hal ini bisa saja terjadi perubahan dikarenan gerakan proses produksipun banyak factor yang mempengaruhi termasuk kebijakan ekonomi dan politik di Indonesia. 
Faktor-faktor ini menyebabkan tingkat produktifitas berbagai kegiatan sektor modern sering kali tidak banyak berbeda dengan kegiatan yang sama yang terdapat di negara maju. Sebaliknya sektor tradisional menunjukkan perbedaan banyak karena keadaan terdiri dari:

1. Terbatasnya pembentukan modal dan peralatan industri disebabkan karena Indonesia masih merupakan negara berkembang dan adanya ledakan bonus demografi yang tidak diimbangi jumlang lapangan kerja

2. Kekurangan pendidikan dan pengetahuan berdampak pada kemampuan dan kompetensi sumber daya manusia dalam penguasaan kerja.

3. Penggunaan teknik produksi yang sederhana menyebabkan hasilprokusi minim kualitasnya.

4. Organisasi produksi yang masih tradisional., dalam hal ini manajemen tata kelola perusahaan masih belum optimal.

Dalam perkembangan teknologi, transfer pengetahuan antar perusahaan memberikan insentif bagi aglomerasi kegiatan ekonomi. Informasi diperlakukan sebagai barang publik yang dikonsumsi masayakat,dengan kata lain tidak ada persaingan dalam memperolehnya. Namun setiap perusahaan hatus menganalisa pasar dan reaksi pasar. Komunikasi yang terjadi menjadi bentuk difusi informasi ini kemudian menghasilkan manfaat bagi masing-masing perusahaan. Dengan mengasumsikan bahwa masing-masing perusahaan menghasilkan informasi yang berbeda-beda, manfaat interaksi meningkat seiring dengan jumlah perusahaan. Karena interaksi ini informal, perluasan pertukaran informasi menurun dengan meningkatnya jarak. Hal inimemberikan insentif bagi pengusaha untuk berlokasi dekat dengan perusahaan lain sehingga menghasilkan aglomerasi. Perusahan-perusahaan yang jaraknya saling berdekatan rata-rata saling terkait akan kebutuhan perusahaan.

Disamping keuntungan skala ekonomis tersebut, aglomerasi mempunyai keuntungan lain yaitu menurunnya biaya tarnsportasi. pemusatan industri padasuatu daerah akan mendorong didirikannya perusahaan jasa angkutan dengansegala fasilitasnya. Dengan adanya fasilitas tersebut, industri-industri tidak perlu menyediakan atau mengusahakan jasa angkutan sendiri. Sebuah proses aglomerasi merangsang pertumbuhan di atas kemajuan teknologi, jika tidak, pertumbuhan akan lebih rendah daripada tingkat kemajuan teknologi. Beberapa orang mengatakan bahwa aglomerasi atau konsentrasi yang memungkinkan adanya peningkatan tingkat output akan menciptakan kekayaan, namun di sisi lain kekuatan sentrifugal biaya transaksi bertolak belakang dengan kekuatan sentripetal dari skala ekonomi. Adanya konsentrasi kegiatan ekonomi selain akan memungkinkan terjadinya peningkatan nilai output juga akan menimbulkan peningkatan biaya transaksi sehingga utilitasnya menjadi rendah. Inilah alasan mengapa dalam jangka panjang aglomerasi belum tentu bernilai positif. Nilai aglomerasi dapat bernilai negatif atau mungkin nol, tergantung pada nilai parameternya. Dalam kasus tertentu adanya perubahan nilai aglomerasi akan menunjukkan hasilnya dalam jangka panjang dimana tingkat pertumbuhan ekonomi per kapita sesuai dengan tingkat pertumbuhan teknologi sehingga mudah untuk mengidentifikasi keseimbangan yang merupakan trade off teknologi dan trade off konsumsi modal 
Aglomrasi industry yang terjadi di 5 daerah aglomerasi Jawa timur menyebabkan geographical distribution dalam sektor industridan hal ini sangat berpengaruh penting dalam memahami konsep aglomerasi. Dari prespektif pengembangan bisnis, pemetaan industri sangat berdampak dalam membantu mengambil keputusan dan tindakan untuk menentukan lokasi produksi. Lokasi yang dipilih berdasarkan ketersediaan tenaga kerja yang potensial dan memiliki keterampilan yang sesuai kebutuhan perusahaan serta jarak dari pasar dan pemasok input produksi. Pemetaan industri juga dapat digunakan oleh pemerintah selaku pembuat kebijakan untuk menentukan prioritas dan alokasi sumber daya yang tepat.

Apabila kita cermati, kasus-kasus pencemaran dan kerusakan lingkungan pada umumnya justru terjadi di zona industri (baik yang berdiri sendiri maupun yang berada di kawasan industri). Misalnya pencemaran udara dan pencemaran sungai hingga pencemaran air tanah yang banyak dikeluhkan masyarakat. Kasus-kasus lingkungan menunjukkan kendati industri telah menempati lokasi yang benar tetapi masih saja menimbulkan masalah.Faktor penyebabnya memang bukan hanya sepihak. Pertama, pihak industri yang memang tidak mempunyai kepedulian terhadap lingkungan. Kedua, lemahnya pengawasan dari pemerintah. Karena lemahnya pengawasan, sesuatu yang masuk dalam kategori pelanggaran lingkungan sering dianggap sebagai sesuatu yang biasa. jika demikian akan sangat sia-sia penataan ruang untuk kawasan industri oleh pemerintah, serta amdal bersama satu kawasan.

Lahan industri sebagai zona aglomerasi industri merupakan faktor yang sangat penting bagi industri, bahkan faktor utama. Suatu bangunan industri berdiri di atas suatu lahan yang mempunyai karakteristik tertentu. Karakteristik lahan yang mendukung terjadinya aglomerasi industri mengenai aspek biofisik yang perlu dipertimbangkan dalam penentuan lokasi industri. Aspek tersebut salah satunya kondisi yang memengaruhi aglomerasi industri.

Suatu wilayah industri tentu juga menjadi pusat kegiatan dari pekerjanya. Kondisi relief dan kemiringan lereng akan memengaruhi keterjangkauan tenaga kerja. Jika kondisi lahan memiliki kemiringan lereng datar hingga landai pasti akan memudahkan menjangkau setiap lokasi. Kemudahan dalam menjangkau setiap tempat di lokasi tersebut tidak hanya dialami oleh tenaga kerja tetapi juga kendaraan sebagai alat transportasi.Kondisi bentang alam mempengaruhi pemusatan industri.

\section{KESIMPULAN DAN SARAN}

\section{Kesimpulan}

Aglomerasi industri akan menimbulkan disparitas desa-kota. Terkonsentrasinya kegiatan ekonomi di suatu tempat akan mengakibatkan terjadinya mobilitas penduduk ke tempat tersebut. Hal ini dapat menyebabkan daerah asal ditinggalkan oleh penduduknya dan kegiatan ekonomi berjalan lambat. Semakin jauhnya jarak antara penduduk kaya dan penduudk miskin merupakan masalah yang perlu diselesaikan.Masalah ini dapat dieliminir dan dikikis secara perlahan-lahan dengan melakukan kaji ulang terhadap strategi pembangunan dengan segala kebijakan-kebijakan 
publik dan kebijakan sosial yang mengikutinya. Distribusi investasi yang merata harus diupayakan sehingga wilayah-wilayah terbelakang dapat mengejar ketertinggalannya menuju pada kondisi merataAglomerasi industri, aglomerasi tersebut memliki arti pengumpulan dan pemusatan di lokasi atau awasan tertentu. Munculnya aglomerasi industri karena adanya para prilaku ekonomi yang berupaya mendapatkan penghematan aglomerasi, baik penghematan lokalisasi maupun penghematan urbanisasi.

Tujuan pokok mempertimbangkan faktor-faktor yang memengaruhi lokasi industri adalah menemukan lokasi optimal (optimum location), yaitu lokasi terbaik secara ekonomi dan lingkungan.Bagi pelaku industri, keuntungan ekonomi sangat dipertimbangkan dalam penentuan lokasi industri.Keuntungan maksimal dapat diperoleh apabila biaya produksi sangat rendah dan pendapatan sangat tinggi. Tetapi, bukan hal yang aneh jika jarang sekali ditemukan dua hal tersebut di tempat dan dalam waktu yang sama. Mungkin di satu lokasi bisa didapatkan biaya produksi murah tetapi wilayah pasaran sempit.Atau berlaku hal sebaliknya, yaitu wilayah pasaran luas tetapi biaya produksi sangat tinggi.Pada kondisi yang demikian sarana dan prasarana transportasi sering digunakan sebagai pemecahan, yaitu untuk menjangkau pasar atau mendatangkan komponen produksi.Jadi, transportasi menjadi sangat terkait dengan industri.Bahkan, aglomerasi industri juga dipengaruhi oleh faktor sarana transportasi..

Lokasi industri merupakan tempat berlangsungnya suatu kegiatan industri pada suatu wilayah di permukaan bumi. Dengan pengertian lain,lokasi industri merupakan suatu tempat dimana industri itu melakukan kegiatan fisik yang melibatkan semua factor-faktor produksi di perusahaan. Jika dianalisa dengan 2 pendekatan penting dalam mempelajari lokasi indutri:

1. Wilayah dan cara untuk menilai alas an mengapa lokasi tertentu memiliki daya tarik untuk kegiatan industry pada umumnya baik dilihat dari skala lokal maupun internasional. Pendekata yang lainnya yaitu industri dalam perspektif dan berusaha untuk menjelaskan mengapa suatu industry individu atau perusahaan tertarik pada suatu lokasi tertentu.

2. Pendekatan ini menunjukkan bahwa suatu jenis industri akan berlokasi sesuai dengan kebutuhannya dan harus mengikuti aturan yang diterapkan masing-masing daerah.

\section{Saran}

Suatu kawasan industri selayaknya terdiri atas industri individual yang berdiri sendiri dan industri-industri yang mengelompok dalam kawasan industri (industrial estate) dan terjadinya pertumbuhan (growth centre), aglomerasi merupakan salah satu instrumen untuk memacu pertumbuhan ekonomi serta memberikan tetesan ke bawah (trickle down effect) pada daerah sekitar aglomerasi maupun daerah terbelakang. Selain itu, dari segi pengelolaan lingkungan aglomerasi industri sebaiknya lebih menguntungkan. Apabila ditinjau dari aspek lingkungan, dengan pengelompokan industri di suatu lokasi akan lebih mudah dikelola. Apalagi jika industri-industri tersebut berada pada satu kawasan (industrial estate), maka pengelolaan limbah secara terintegrasi (integrated waste management) dengan mudah bisa dilakukan.Dengan kebijakan pemerintah pusat dan daerah terkait amdal srhingga polusi tanah,air dan udara bisa diminimalisir lebih optimal.Sehingga industri yang berada pada satu kawasan tidak perlu 
menyusun amdal sendiri.Amdalnya adalah amdal kawasan, tetapi masing-masing industri mempunyai kawasan untuk melakukan pengelolaan lingkungan sesuai dengan spesifikasi kegiatannya. Tetapi, apakah dengan ini pencemaran lingkungan tidak terjadi dan dampak industri di kawasan zona industri telah memenuhi kaidah lingkungan

Peran Pemerintah Pusat dan Daerah dalam hal Undang-undang,kebijakan dan peraturan terhadap ketenagakerjaan,sistem penggajian dan tata kelola downsizing yang sifatnya masih belum optimal dan penerapannya lebih pada kebijakan masing-masing perusahaan. Infrastruktur yang lengkap sangat mendukung bagi perkembangan industri. Pada lokasi industri yang memiliki infrastruktur atau prasarana lengkap akan cepat berkembang. Infrastruktur yang diperlukan bagi perkembangan industri antara lain jaringan jalan, listrik, air, dan telepon. Pembangunan infrastruktur tersebut membutuhkan biaya tinggi.Biaya pembangunan infrastruktur jauh lebih kecil dan hemat jika industri-industri dibangun dalam suatu lokasi.Kelengkapan infrastuktur pada lokasi industry menjadi daya tarik bagi industri-industri baru untuk menempatinya, sehingga terjadi pengelompokan atau aglomerasi industri.Ternyata banyak pertimbangan yang digunakan untuk menentukan lokasi industry

Berdasarkan penjelasan di atas maka dibutuhkan suatu analisis mengenai konsep dasar teori aglomerasi dan lokasi dalam menentukan kawasan industri, dimana dengan adanya konsep dasar tersebut dapat menjadi prinsip dalam pemilihan aglomerasi dan lokasi yang terbaik dan menguntungkan secara ekonomi bagi industri itu sendiri.Peran pemerintah daerah maupun pusat sangat berpengaruh.Kebijakan yang diterapkan sebaiknya tidak hanya menguntungkan salah satu pihak,melainkan semua pihak yang terlibat dalam proses manajemen dan produksi di setiap perusahaan.

\section{DAFTAR PUSTAKA}

Agustin, Niken. 2012. Pegaruh Aglomerasi Terhadap Perekonomian.

Http://Nikenagustin.Blogspot.Com/2012/03/Pengaruh-Aglomerasi-Terhadap.Html . Diakses Pada Tanggal 7 Desember 2017 12:22

Bps. 2016. Economic Census Complete Count Result: Indonesia. Jakarta: Biro Pusat Statistik,

Bps. 2016. Statistikal Yearbook Of Indonesia 1998. Jakarta: Biro Pusat Statistik.

Ditafebriyanti.2010. Konsep Dasar Teori Penentuan Lokasi Industri. Http://Edukasi.Kompasiana. Com/2012/04/29/Implikasi-Teori-Lokasi-Terhadap-Penentuan-Lokasi-Industri-DiKompleks-Sier-Surabaya-458428.Html . Diakses Pada Tanggal 15 Oktober 2017

Erni, A Dan Tri H. 2010. Aglomerasi Industri

Http://Ssbelajar.Blogspot.Com/2012/10/Aglomerasi-Industri.Html . Diakses Pada Tanggal 15 Oktober 2017 6:05 
Iskandar. Metodologi Penelitian Pendidikan Dan Sosial (Kuantitatif Dan Kualitatif). Jakarta: Gp Press, 2009.

Kuncoro. 2002. Manajemen Perbankan, Teori Dan Aplikasi. Jakarta: PT. Indeks Kelompok Gramedia.

Kuncoro, M. 2000. Ekonomi Pembangunan: Teori, Masalah Dan Kebijakan. Yogyakarta: Upp Amp Ykpn,

Kuncoro, M. 2002. Analisis Spasial Dan Regional: Studi Aglomerasi Dan Kluster Industri Di Indonesia. Yogyakarta: Upp Amp Ykpn.

, M, 2003. Metode Riset Untuk Bisnis \& Ekonomi: Bagaimana Meneliti \& Menulis Tesis. Jakarta: Penerbit Erlangga.

Kuncoro, M., A. Adji, Dan R. Pradiptyo. 1997. Ekonomi Industri: Teori, Kebijakan Dan Study Empiris Di Indonesia. Yogyakarta: Widya Sarana Informatika.

Kuncoro, M., Dan Arifin Z. 2002. “Konsentrasi Spasial Dan Dinamika Pertumbuhan Industri Manufaktur Di Jawa Timur, ” Jurnal Empirika 11 (1)

Meyer Et Al., 1998; Lâmsâ \& Savolainen, 2000; Knudsen Et Al., 2003. The Effects Of Organizational Downsizing And Layoffs On Organizational Commitment: A Field Research

Miyauchi, Yasunari. 2002. "Industrial Exchanges Between Cluster Across Countries," International Joint Research Project”. Japan Institute Of Developing Economies

Mowen, John C, Michael Minor. 2001. Consumer Behavior, 5 Th. Harcourt Inc. Usa. O’sulvivan, A. 1996. Urban Economics, 3 Rd Edition.

Nugraheni, Khoiri. 2009. Aglomerasi Industri. Http://Prezi.Com/Vokjw9tupa5c/AglomerasiIndustri-Kawasan-Industri Kawasan-Berikat-Rel/. Diakses Pada Tanggal 15 Oktober 2017

Richard D. Irwin, Chicago. Porter, M.E. 1988. "Cluster And The New Economics Of Competition," Harvard Business Review. Prahasta, Edi. 2001.

Konsep-Konsep Dasar Sistem Informasi Geografis. Informatika, Bandung. Pribadi, K.N. 1993. "Implikasi Pertumbuhan Ekonomi Dan Industri Di Wilayah Mega Urban Jakarta Bandung," Jurnal Perencanaan Wilayah Dan Kota Edisi Khusus 1993.

Risdwiyanto, A,. Dan B.S. Dharmesta. 2001. "Pengembangan Konsep Jasa Pendidikan Tinggi Berbasis Keinginan Konsumen Potensial," Jurnal Ekonomi Dan Bisnis Indonesia 
Robbins, Stephen P. 2003. Perilaku Organisasi, Edisi 8. Jilid 2. Jakarta: PT. Prenhallindo , Stephen P. 2003. Perilaku Organisasi. Jakarta: PT. Indeks Kelompok Gramedia.

, Stephen P. 2003. Organizational Behaviour. Upper Saddle River, New Jersey: PrenticeHall, Inc.

, Stephen P. 2008. Perilaku Organisasi, Edisi 12. Jakarta : Penerbit Salemba Empat.

Siegel, Sidney. 1997. Statistik Nonparametrik: Untuk Ilmu Sosial. Jakarta: Penerbit PT.. Gramedia Pustaka Utama.

Schein, Edgar H. 2009. The Corporate Culture Survival Guide. San Fransisco: Jossey Bass, Published.

Sudjana. 2002. Metode Statistika, Edisi 6. Bandung : Penerbit Tarsito.

Tarigan, Robinson. 2003. Ekonomi Regional: Teori \& Aplikasi. Bumi Aksara, Jakarta

Ueki, Yasushi. 2002. "Industrial Agglomeration And Regional Growth In Korea Focusing On The Software And Ict Service Sector," International Joint Research Project. Japan Institute Of Developing Economies.

Tutus Alun Asoka Sakti . Jurnal Ekonomi Dan Bisnis Indonesia Vol. 22, No. 1, 2007, 1 - 22 Analisis Aglomerasi Dan Faktor-Faktor Yang Mempengaruhi Terkonsentrasinya Lembaga Pendidikan Tinggi Di Pulau Jawa

Undang - Undang No. 13 Pasal 61 Tahun 2003 Tentang Ketenagakerjaan.

Wahyuddin, M. 2004. Industri Dan Orientasi Ekspor: Dinamika Dan Analisis Spasial. Muhammaddiyah University Press, Surakarta.

Wibowo, Wisnu Ari. 2013. Pengaruh Faktor Aglomerasi Industri, Angkatan Kerja Dan Tingkat Upah Terhadap Pertumbuhan Ekonomi Kabupaten/Kota Di Provinsi Jawa Tengah Tahun 2005-2010. Skripsi Tidak Diterbitkan Universitas Negeri Semarang. 